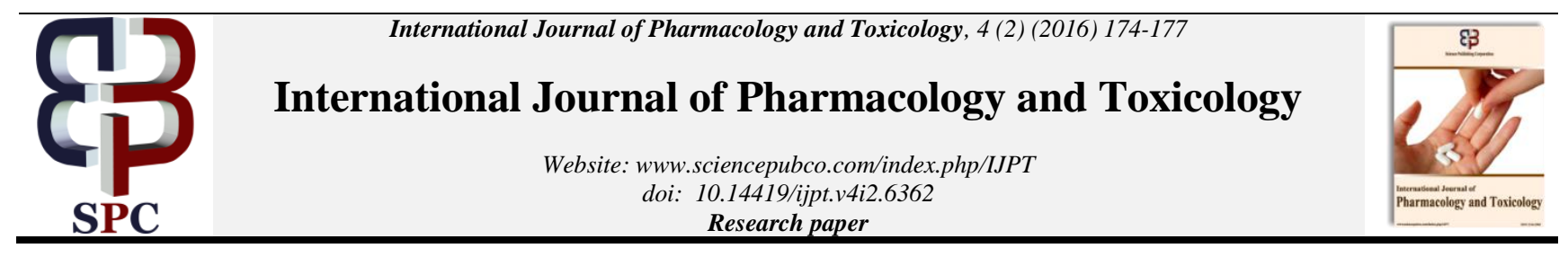

\title{
Effects of food-chain mediated metal exposures on phosphatases' profile in rats
}

\author{
Richard Omonigho OVIE *, Samuel Ogheneovo ASAGBA \\ Department of Biochemistry, Faculty of Science, Delta State University, P.M.B. 1 Abraka, Nigeria \\ *Corresponding author E-mail: omo_richard@yahoo.com
}

\begin{abstract}
This study seeks at investigating the separate and combined toxicities of Arsenic (As) and Cadmium (Cd) administered along food-chain. The natural food-chain was mimicked by exposing rats to diet containing milled Cd and As-exposed (at a dose of $0.4 \mathrm{mg} / 100 \mathrm{ml}$ each) catfish as source of protein. Control groups were fed with normal formulated rat feed with non-metal contaminated fish as source of protein. The effects of $\mathrm{Cd}$ and As exposures were sought by determining indices of plasma and lysosomal membrane integrity in plasma and organs of the rats after three months exposure time. The results depict that $\mathrm{Cd}$ and As exposures in the rats led to bioaccumulation of the metals in their plasma and organs. The results gotten revealed significance $(\mathrm{p}<0.05)$ in gain of body weight in both $\mathrm{Cd}$ and As exposed rats when control is compared to them. Phosphatases' activities (ALP and ACP) in the plasma and vital organs were also significant in the metal inoculated rats when the control is compared to them. These results explained that arsenic and cadmium forms free radicals which cause stress due to oxidation, kidney impairment and immunologic disorders.
\end{abstract}

Keywords: Arsenic; Cadmium; Exposures; Food-Chain; Rats.

\section{Introduction}

Food-chain contamination is part of the common routes for entry of metals into the animal system (Oscarson et al. 1992) and therefore, monitoring the bioavailability pools of metals in contaminated feed is of uttermost concern. Cadmium and Arsenic can be transported, dispersed to and accumulated in plants, to animals and passed across the food chain to humans, Hongyu et al. (2005). Since mineral concentrations may consistently biomagnifies from one tropic level to another, animals higher along the chain of food may accumulate more toxins than the constituents intended to provide, Montero et al. (1996). It is known that exposure in diets is the major route for metal bioaccumulation of many marine and terrestrial animals (Talmage \& Walton 1991, Shore 1995, Wang \& Fisher 1999, Komarnicki 2000). Metalloids and metals that accumulate in biological tissue may be converted to other chemical forms and passed on via numerous pathways. Humans, as the final consumers in the chain of food, are thus the likely recipients of enormous amounts of minerals from infected food and may accumulate same in their organs (Oskarson et al. 1992). These metals affect every living organism and have possible toxic impact on all levels of food-chain (Sami \& Druzykli 2003). The effects of the toxicity are acute, when large amounts are ingested or the element is particularly toxic or chronic, with toxicity only being noticed after a long time (Toens et al. 1998, Bahemuka \& Mobufu 1999, Ikeda et al. 2000). The latter may be the result of the bioaccumulation process across the food chain (Lacatus et al. 1996, Turkdogan et al. 2003).

Cadmium $(\mathrm{Cd})$, a metal common in native environments, is also extremely toxic (Wang \& Fisher 1999). Cd pollution has been known to be a potential health problem to wild animals as found by Toens et al. in 1998. Its uses in technology have escalated to increasing amounts in the ecosystem and also in body of humans
(Mah \& Jalilehvand 2010). From a worldly view, human activities have led to increase in pollution. Present studies indicate that $\mathrm{Cd}$ is highly toxic towards multiple organs and a potent immunetoxicant. Researches on humans and rodents have depicted influence on immune system function (Pathak \& Khandelwal 2006). Several literatures have explained that $\mathrm{Cd}$ exposure has the tendency to result to stress due to oxidation, reduce lymphocytes function and may ensue apoptosis and necrosis on humans and also rodents (Pathak \& Khandelwal 2006, Pathak \& Khandelwal 2007).

Arsenic exists naturally in 3 allotropic states of alpha, beta and gamma. The popular numbers of oxidation are $+5,+3$ and -3 , which enable the element to give compounds of organic and nonorganic nature in the ecosystem and in humans (Orloff et al. 2009), When carbon and hydrogen is bonded to arsenic, it is called organic, whereas it is inorganic when chlorine, sulphur and oxygen are combined to it.

Examples of inorganic arsenic are arsenite (As (III)) and arsenate (As (V)) that a methyl group can attach to, to form monomethylarsonic acid (MMA (V)) or removed as seen with arsinic acid having 2 methyl groups. Inorganic arsenic metabolism occurs through two electron decrease of arsenic having valency of 5 to one having valency of 3 , which require glutathione, then formation of arsenic of organic nature with valency of 5 through oxidative methyl group addition (Hughes 2002). Organic arsenic is found to be less toxic than inorganic (Shi et al. 2004, Valko et al. 2005). Arsenic is harmful to majority of organs, of which the kidney may be the primary target (Cohen et al. 2006). The extent of as poisoning depends on many variants like dose, individual susceptibility and age. While long-term exposures to arsenic will affect the vesicle system and induces hypertension with cardiovascular diseases, the short-term arsenic exposures can result to cardiomyopathy and hypotension. The most prevalent effect of longterm as toxicity on the neuron is peripheral neuropathy and mani- 
festation of toxic hepatitis in the gastro-intestine followed by elevation of enzymes of the hepatocytes.

The consuming of exposed arsenic, cadmium diets along several metals can seriously reduce the body reserves of iron, ascorbic acid and other vital nutrients resulting to distortion of immune defense, retardation of growth of uterus, abnormal epidemics linked to malnutrition (Iyengar \& Nair 2000).

\section{Materials and methods}

\subsection{Animals}

Male Wistar (no. 16) albino rats, mean weight $129 \pm 4 \mathrm{~g}$, were utilized for this study. The rats were obtained at the Delta State University's Animal House in Pharmacy Faculty, Abraka. Prior to commencement of the experiment, the rats were kept for 10-day period in cages to help them get use to the new climate.

\subsection{Preparation of the diet}

In order to simulate exposure to $\mathrm{Cd}$ and As through the food chain, four diets ( 1 control and 3 tests) that differed in terms of the nature of the protein were formulated. The test diets contained milled $\mathrm{Cd}$, as and $\mathrm{Cd}+\mathrm{As}$ exposed fish as a source of protein, while the control diet contained milled non-Cd and As exposed fish. Other components of the diets were corn starch (Livestock Feed depot, Warri), multivitamin/minerals mix (Vetindia Pharmaceuticals Limited, India), vegetable oil (obtained locally in Abraka, Nigeria), cellulose (analytical grade) and granulated refined sugar (obtained from Abraka market).

\subsection{Experimental design}

The rats were divided into four experimental groups of four rats each and housed singly in metabolic cages. Rats in the cages were maintained for 3 months on the control, $\mathrm{Cd}$, As and $\mathrm{Cd}+\mathrm{As}$ test diet respectively. They were allowed free access to water any time they are tasty.

\subsection{Collection and treatment of samples}

At the end of the specified period of exposures, the animals were fasted for three hours and weighed before sacrificed under chloroform anaesthesia. While under anesthesia, each rat was slaughtered by heart puncture, using a hypodermic syringe and needle. The blood collected from the heart was transferred to heparinized tubes which were carefully swirled. Plasma was later obtained by centrifugation at 4000rpm for 10 minutes. The heart, liver and kidney were quickly excised, placed on ice and subsequently weighed. Portions of the liver, heart and kidney were homogenized to give $10 \%$ homogenates and centrifuged at 4000rpm for 10 minutes to obtain clear supernatants for biochemical analysis.

\subsection{Determination of various biochemical parameters}

The plasma and the supernatants obtained from the heart, kidney and liver were used for the determination of the activities of ALP (E.C. 3.1.3.1) and ACP (E.C. 3.1.3.2). ALP activity was assayed by the method of Roy (Roy 1970) based on the colorimetric endpoint method where the alkaline phosphatase acts upon the AMPbuffered sodium thymolphthalein monophosphate to produce a blue chromogen, which is measured photometrically using Teco Diagnostic test kits. The activity of the enzyme is expressed in international unit per litre. ACP activity was determined by the method of Hillman (Hillman 1971) as adapted in Teco Diagnostic test kits' kinetic method in which a coloured complex is produced when the $\alpha$-Naphthol released from the substrate $\alpha$ Naphthylphosphate by acid phosphatase is coupled with Fast Red TR. The activity of the enzyme is expressed in units per litre. One International Unit is defined as the amount of enzyme that cata- lyzes the transformation of one micromole of substrate per minute under defined conditions.

\subsection{Statistical analysis}

The results were expressed as mean \pm SEM. Statistical analysis was done by one-way analysis of variance (ANOVA) using a computer software package (SPSS version 16.0, SPSS Inc. Cary, NC, USA). Least significant difference (LSD) test was used to check mean difference between the test and control groups. Statistical significance was considered at $\mathrm{P}<0.05$.

\section{Results}

The body weight gain and organ/body weight ratios in rats are presented in Table 1.

The body weight gain of rats administered $\mathrm{Cd}$ and As contaminated diet was significantly decreased $(p<0.05)$ relative to control. The results indicate that there was a body weight loss of rats exposed to $\mathrm{Cd}$ and As in diet. Conversely, no significant difference ( $>0.05$ ) was observed in the body weight gain of rats fed a combination of $\mathrm{Cd}$ and $\mathrm{As}$ in diet as compared to control. The organ/body weight ratios for the liver and heart were not significantly different in all the experimental groups. Similarly, no significant difference was observed in the kidney/body weight of rats fed diet containing $\mathrm{Cd}$ and combination of $\mathrm{Cd} / \mathrm{As}$ relative to control. On the other hand, this parameter was significantly increased in rats fed As via the food chain. Thus the study showed that the organ/body weight ratios of the rats were influenced by $\mathrm{Cd}$ and $\mathrm{As}$ exposures.

Table 1: Effects of Food-Chain Mediated Metal Exposures on Body Weight Gain and Organ/Body Weight Ratios in Rats

\begin{tabular}{lcccc}
\hline Parameter & Control & $\mathrm{Cd}$ & $\mathrm{As}$ & $\mathrm{Cd}+\mathrm{As}$ \\
\hline $\begin{array}{l}\text { Body weight } \\
\text { gain }(\mathrm{g})\end{array}$ & $77.50 \pm 7.60^{\mathrm{a}}$ & $27.10 \pm 7.91^{\mathrm{b}}$ & $39.28 \pm 11.66^{\mathrm{b}}$ & $80.08 \pm 5.40^{\mathrm{a}}$ \\
$\begin{array}{l}\text { Liver/body } \\
\text { weight ratio }\end{array}$ & $0.03 \pm 0.00^{\mathrm{a}}$ & $0.03 \pm 0.00^{\mathrm{a}}$ & $0.04 \pm 0.00^{\mathrm{a}}$ & $0.03 \pm 0.00^{\mathrm{a}}$ \\
$\begin{array}{l}\text { Heart/body } \\
\text { weight ratio }\end{array}$ & $0.00 \pm 0.00^{\mathrm{a}}$ & $0.00 \pm 0.00^{\mathrm{a}}$ & $0.01 \pm 0.00^{\mathrm{a}}$ & $0.00 \pm 0.00^{\mathrm{a}}$ \\
$\begin{array}{l}\text { Kidney/body } \\
\text { weight ratio }\end{array}$ & $0.01 \pm 0.00^{\mathrm{a}}$ & $0.01 \pm 0.00^{\mathrm{a}}$ & $0.01 \pm 0.00^{\mathrm{b}}$ & $0.01 \pm 0.00^{\mathrm{a}}$ \\
\hline $\begin{array}{l}\text { Values are given as mean } \pm \mathrm{SEM}, \mathrm{n}=4 . \\
\text { superscript letter in the same column differ significantly at }(\mathrm{p}<0.05) .\end{array}$
\end{tabular}

The effects of $\mathrm{Cd}$, As and a combination of both metals on plasma and organ ALP and ACP activity in rats is presented in Table 2. The plasma, liver, heart and kidney ALP and ACP activity in rats given $\mathrm{Cd}$, As and a combination of $\mathrm{Cd}$ and $\mathrm{As}$ contaminated diet was significantly increased $(\mathrm{p}<0.05)$ relative to control. Similarly, multiple comparisons of organ ALP activity in Cd, As and Cd+As contaminated rats showed significant increase relative to control. Plasma ALP and tissue ACP activity in Cd, As and a combination of $\mathrm{Cd}$ and $\mathrm{As}$ contaminated rats showed no significant difference ( $>0.05$ ) when compared to one another, while plasma ACP activity in the rats administered a combination of $\mathrm{Cd}$ and As significantly increased when compared to those given $\mathrm{Cd}$ and As separately. However, the hepatic ALP in rats fed As contaminated diet was significantly decreased as compared to those fed either $\mathrm{Cd}$ or combination of Cd and As. Similarly, the renal ALP was significantly decreased in rats fed a combination of $\mathrm{Cd}$ and As compared to those fed either $\mathrm{Cd}$ or As diet. This study reveals that $\mathrm{Cd}$ and As exposures via the food-chain for three months altered phosphatases' activities in rats. 
Table 2: Effects of Food-Chain Mediated Metal Exposures on Plasma And Organ ALP and ACP Activities in Rats.

\begin{tabular}{lcccc}
\hline Parameter & Control & Cd & As & Cd + As \\
\hline Plasma & & & & \\
ALP & $30.87 \pm 0.57^{\mathrm{a}}$ & $\begin{array}{c}43.16 \pm 3.60^{\mathrm{b}} \\
(39.81 \%)\end{array}$ & $\begin{array}{c}42.64 \pm 3.11^{\mathrm{b}} \\
(38.13 \%)\end{array}$ & $\begin{array}{c}42.64 \pm 1.52^{\mathrm{b}} \\
(38.13 \%)\end{array}$ \\
ACP & $7.46 \pm 1.49^{\mathrm{a}}$ & $\begin{array}{c}13.43 \pm 2.86^{\mathrm{b}} \\
(80.03 \%)\end{array}$ & $\begin{array}{c}10.45 \pm 2.86^{\mathrm{b}} \\
(40.08 \%)\end{array}$ & $\begin{array}{c}20.90 \pm 3.86^{\mathrm{c}} \\
(180.16 \%)\end{array}$ \\
Liver & & & & \\
ALP & $19.81 \pm 5.16^{\mathrm{a}}$ & $53.06 \pm 2.24^{\mathrm{b}}$ & $35.87 \pm 1.73^{\mathrm{c}}$ & $73.25 \pm 4.96^{\mathrm{d}}$ \\
& & $(167.84 \%)$ & $(81.07 \%)$ & $(269.76 \%)$ \\
ACP & $34.12 \pm 0.00^{\mathrm{a}}$ & $51.18 \pm 9.85^{\mathrm{b}}$ & $51.18 \pm 7.06^{\mathrm{b}}$ & $51.18 \pm 9.85^{\mathrm{b}}$ \\
& & $(50.00 \%)$ & $(50.00 \%)$ & $(50.00 \%)$ \\
Heart & & & & \\
ALP & $22.43 \pm 4.65^{\mathrm{a}}$ & $47.83 \pm 5.32^{\mathrm{b}}$ & $60.54 \pm 0.75^{\mathrm{c}}$ & $65.02 \pm 1.43^{\mathrm{c}}$ \\
& & $(113.24 \%)$ & $(169.91 \%)$ & $(189.88 \%)$ \\
ACP & $34.12 \pm 0.00^{\mathrm{a}}$ & $34.12 \pm 0.00^{\mathrm{a}}$ & $42.65 \pm 8.53^{\mathrm{b}}$ & $42.65 \pm 8.53^{\mathrm{b}}$ \\
& & $(00.00 \%)$ & $(25.00 \%)$ & $(25.00 \%)$ \\
Kidney & & & & \\
ALP & $14.95 \pm 1.22^{\mathrm{a}}$ & $50.82 \pm 4.05^{\mathrm{b}}$ & $66.52 \pm 6.73^{\mathrm{c}}$ & $35.12 \pm 0.75^{\mathrm{d}}$ \\
& & $(234.93 \%)$ & $(344.95 \%)$ & $(134.92 \%)$ \\
ACP & $34.12 \pm 0.00^{\mathrm{a}}$ & $51.18 \pm 9.85^{\mathrm{b}}$ & $51.18 \pm 9.85^{\mathrm{b}}$ & $51.18 \pm 9.85^{\mathrm{b}}$ \\
& & $(50.00 \%)$ & $(50.00 \%)$ & $(50.00 \%)$ \\
\hline
\end{tabular}

Abbreviations as in Table 1

The activities of the phosphatases are in IU/L.

Figures in brackets represent percentage inhibition relative to control.

\section{Discussion}

Heavy metals are not biodegradable and persist in the environment for long periods causing serious ecological problems. In addition, some toxic metals may mimic essential metals and thereby gain access to important molecular targets. These toxic metals enter into organisms via food, drinking water and air and are biopersistent pollutants that accumulate at the top of the food-chain (Scheifer et al. 2006). Thus the food-chain is one of the natural routes of entry of heavy metals into humans. However, in most animal studies on heavy metal toxicity, exposures to metals is not often through the food-chain, but by direct addition to the food offered to the experimental animals.

The objective of the present study was to determine the effects of food-chain mediated metal exposures on phosphatases' profile in rats. The findings of the study revealed a decrease body weight gain of rats administered $\mathrm{Cd}$ and As via the food-chain (Table 1). An increased kidney/body weight ratio was also observed in rats fed As contaminated diet. The decreased body weight gain and increased kidney/body weight ratio are indications of toxicity of these metals. Changes in body weight gain and organ/body weight ratio have been used as indices of toxicity of chemicals (Timbrell 1991). The changes observed in the body weight gain of the rats exposed to these metals correlates with the findings of Prabu and Nabi (Nabi et al. 2005, Prabu et al. 2013).

Quantitative assessment of enzyme is a reliable indicator of stress imposed on the organism by environmental pollutants such as heavy metals (Cheng 1988). Many physiological processes including activity of many lysosomal hydrolytic enzymes are inhibited by heavy metals even though these metals may also activate certain enzymes. Two important enzymes that can be influenced by heavy metals are ALP and ACP both differing in their subcellular distribution. These enzymes were also monitored in the plasma and organs of rats exposed to $\mathrm{Cd}$, As and combination of both metals in diet. The findings of the study revealed that plasma and organ levels of ALP and ACP were influenced by separate treatment with these metals and treatment with both metals (Table 2). The increased activity of ALP in the liver and other organs of the exposed rats and the corresponding increase in the plasma may be due to de novo synthesis of the enzyme molecule. ALP is a marker enzyme for the plasma membrane and endoplasmic reticulum (Wright \& Plummer 1974). It is often employed to assess the integrity of the liver plasma membrane (Akanji et al. 1993), since it is localized predominantly in the microvilli in the bile canaliculi. Since ALP hydrolyzes phosphate monoesters, the enzymes hyperproduction observed in the metal exposed rats could constitute a threat to the life of the cells that are dependent on a variety of phosphate esters for their vital processes (Butterworth \& Moss 1966) as it may lead to indiscriminate hydrolysis of phosphate ester metabolites of the liver. Consequently, this may adversely affect the facilitation of the transfer of metabolites across the cell membrane. It follows therefore that such hyper-production of ALP may also have severe consequences on the architecture of the cells of the affected organs.

Lysosomal response was considered as the most reliable effect observed during stress (Grundy et al. 1996) and ACP is a lysosomal marker enzyme that exists in the tissue and serum (Braun et al 1989). Metals may disrupt lysosomal membrane integrity and cause its destabilization followed by release of stored lysosomal hydrolases into the serum thereby increasing the activity of the enzyme in the serum. The above explanation justifies the hyperactivity of ACP in the plasma and organs of rats after separate and combined treatment with $\mathrm{Cd}$ and As in food (Table 2). The higher activity of ACP in the plasma and organs of metal exposed rats can also be due to the hyper-synthesis of ACP and its subsequent release into the blood occasioned by metal insult. This may be a necessary defensive mechanism in response to metal exposures. Previous studies show that ACP activity in serum can reflect the immune state of the two species of Scallop, A. Irradians and $C$. Farreri (Mu et al. 1999, Liu et al. 2004, Zhang et al. 2005). Interactions between the heavy metals tested can lead to synergism or to antagonism or rather to an addition of the effects. Thus, the decrease in the combined effect of Cd and As on kidney ALP activity (Table 2) as compared to the effect on the same parameter by $\mathrm{Cd}$ and As alone suggest antagonism between these metals.

\section{Conclusion}

In conclusion, this study indicates that $\mathrm{Cd}$ and $\mathrm{As}$ are toxic metals that affects plasma phosphatases and causes degenerative changes in the organs of rats. The inhibition of these enzymes may disturb immune function, cause myocardial damage and generates reactive oxygen species (ROS).

\section{Conflicts of interest}

The authors declare that there are none.

\section{Acknowledgement}

Special thanks to the Staff of the Department of Biochemistry, Delta State University, Abraka for their support.

\section{References}

[1] Akanji MA, Olagoke OA \& Oloyede OR (1993) Effect of chronic consumption of metabisulphite on the integrity of the kidney cellular system. Toxicology 81,173-179. http://dx.doi.org/10.1016/0300483X(93)90010-P.

[2] Bahemuka TE \& Mobufu EB (1999) Heavy metals in edible green vegetables grown along the site of the Simza and Msimbazi River in Dar es Salam in Tanzania. Food Chemistry 66, 63-66. http://dx.doi.org/10.1016/S0308-8146(98)00213-1.

[3] Braun M, Waheed a \& Von Figura K (1989) Lysosomal acid phosphatase is transported to lysosomes via the cell surface. EMBO Journal 8, 12, 3633 - 3640

[4] Butterworth PJ \& Moss DW (1966) Action of neuraminidase on human kidney alkaline phosphatase. Nature 209, 805-810. http://dx.doi.org/10.1038/209805a0.

[5] Cheng TC (1988) In vitro effects of heavy metals on cellular defense mechanisms of $C$. virginica: phagocytic and endocytic indices. Journal of Invertebrate Pathology 51, 215-220. http://dx.doi.org/10.1016/0022-2011(88)90028-6.

[6] Cohen SM, Arnold LL, Eldan M, Lewis AS \& Beck BD (2006) Methylated arsenicals: the implications of metabolism and carcinogenicity studies in rodents to human risk assessment. Critical Re- 
view in Toxicology 36, 99-133.

http://dx.doi.org/10.1080/10408440500534230.

[7] Grundy MM, Moore MN, Howell SM \& Ratcliffe NA (1996) Phagocytic reduction and effects on lysosomal membranes by polycyclic aromatic hydrocarbons, in haemocytes of Mytilus edulis Aquatic Toxicology 34, 273-90. http://dx.doi.org/10.1016/0166445X(95)00044-5.

[8] Hillman GZ (1971) Clinical biochemistry. Clinical Chemistry 3, 273.

[9] Hongyu L, Anne P \& Bohan L (2005) Metal contamination of soils and crop affected by the Cehenzhou lead/ zinc mine spill (Hunan, China). Science of the Total Environment 339, 153-166. http://dx.doi.org/10.1016/j.scitotenv.2004.07.030.

[10] Hughes MF (2002) Arsenic toxicity and potential mechanisms of action. Toxicology Letters 133, 1-16. http://dx.doi.org/10.1016/S0378-4274(02)00084-X.

[11] Ikeda M, Zhang ZW, Shimbo S, Watanabe T, Nakatsu H \& Moon CS (2000) Urban population exposure to lead $(\mathrm{Pb})$ and cadmium in East and South East Asia. Science of the Total Environment 249, 373-384. http://dx.doi.org/10.1016/S0048-9697(99)00527-6.

[12] Iyengar V \& Nair P (2000) Global outlook on nutrition and the environment meeting the challenges of the next millennium. Science of the Total Environment 249, 331-346. http://dx.doi.org/10.1016/S0048-9697(99)00529-X

[13] Komarnicki GJK (2000) Tissue, sex and age specific accumulation of heavy metals $(\mathrm{Zn}, \mathrm{Cu}, \mathrm{Pb}, \mathrm{Cd})$ by populations of the mole (Talpa europaea L.) in a central urban area. Chemosphere 41, 10, 1593 1602. http://dx.doi.org/10.1016/S0045-6535(00)00018-7.

[14] Lacatus R, Rauta C, Carstea S \& Ghelase I (1996) Soil- plant- man relationship in heavy metal polluted rear in Romania. Applied Geochemistry 11, 105-107. http://dx.doi.org/10.1016/08832927(95)00101-8.

[15] Liu SL, Jiang XL, Hu XK, Gong J, Hwang H \& Mai KS (2004) Effects of temperature on non-specific immune parameters in two scallop species: Argopecten irradians (Lamarck 1819) and Chlamys farreri (Jones \& Preston 1904). Aquaculture Research

[16] Mah V \& Jalilehvand F (2010) Cadmium (II) complex formation with glutathione. Journal of Biology and Inorganic Chemistry 15, 441-458. http://dx.doi.org/10.1007/s00775-009-0616-3

[17] Monteiro LR, Costa V, Furness RW \& Santos RS (1996) Mercury concentrations in prey fish indicate enhanced bioaccumulation in mesopelagic environments. Marine Ecology Progress Series 141, 21-25. http://dx.doi.org/10.3354/meps141021.

[18] Mu HJ, Jiang XL, Liu SQ \& Guan HS (1999) Effects of immunopolysaccharide on the activities of acid phosphatase, alkaline phosphatase and superoxide dismutase in Chlamys farreri. Journal of Ocean University, Qingdao 29,463-468.

[19] Nabi AHM, Rahman MM \& Islam LN (2005) Evaluation of Biochemical Changes in Chronic Arsenic Poisoning among Bangladeshi Patients. International Journal of Environmental Research and Public Health 2, 3, 385-393. http://dx.doi.org/10.3390/ijerph2005030002.

[20] Orloff K, Mistry K \& Metcalf S (2009) Biomonitoring for environmental exposures to arsenic. Journal of Toxicology and Environmental Health, B Critical Review 12, 509-524. http://dx.doi.org/10.1080/10937400903358934.

[21] Oskarson AL, Jorham L, Sindberg J, Nilson N \& Abanus L (1992) Lead poisoning in cattle- Transfer of Lead to milk. Science of the Total Environment 111, 83-94. http://dx.doi.org/10.1016/00489697(92)90348-V

[22] Pathak N \& Khandelwal S (2006) Oxidative stress and apoptotic changes in murine splenocytes exposed to cadmium. Toxicology 220, 26-36. http://dx.doi.org/10.1016/j.tox.2005.11.027.

[23] Pathak N \& Khandelwal S (2007) Cytoprotective and immunomodulating properties of piperine on murine splenocytes: An in vitro study. European Journal of Pharmacology 576, 160-170. http://dx.doi.org/10.1016/j.ejphar.2007.07.033.

[24] Prabu SM, Muthumani M \& Shagirtha K (2013) Quercetin potentially attenuates cadmium induced oxidative stress mediated cardiotoxicity and dyslipidemia in rats. European Review on Medical Pharmacological Science. 17, 282 - 295.

[25] Roy AV (1970) Determination of ALP in human serum. Clinical Chemistry 16, 431-431.

[26] Sami K \& Druzykli AL (2003) Predicated spatial distribution of naturally occurring arsenic, selenium and uranium in groundwater in groundwater in South Africa Reconnaisance survey (Report No 1236/1/03). Pretoria: Water Research Commission.

[27] Scheifler R, Coeurdassier M, Morilhat C, Bernard N, Faivre B, Flicoteaux P, Giraudoux P, Noël M, Piotte P \& Rieffel D (2006) Lead concentrations in feathers and blood of common blackbirds
(Turdus merula) and in earthworms inhabiting unpolluted and moderately polluted urban areas. Science of the Total Environment 371 , 197 - 205. http://dx.doi.org/10.1016/j.scitotenv.2006.09.011.

[28] Shi H, Shi X \& Liu KJ (2004) Oxidative mechanism of arsenic toxicity and carcinogenesis. Molecular Cell Biochemistry 255, 67-78. http://dx.doi.org/10.1023/B:MCBI.0000007262.26044.e8.

[29] Shore RF (1995) Predicting cadmium, lead and fluoride levels in small mammals from soil residues and by species-species extrapolation. Journal of Environmental Pollution 88, 3, 333-340. http://dx.doi.org/10.1016/0269-7491(95)93447-8.

[30] Talmage SS (1991) Walton BT. Small mammals monitors of environmental contaminants. Environmental Contamination and Toxicology 119, 47-145.

[31] Timbrell JA (1991) Principle of biochemical toxicology. 2nd edn. (Taylor and Francis ed.) USA p.369.

[32] Toens PD, Stadler W and Wullschleger NJ (1998) the association of groundwater chemistry and geology with a typical lymphocytes (as a biological indicator) in the Pofadder area, (Report No. K5/839). North Western Cape: WRC.

[33] Turkdogan MK, Kulicel F, Kara K, Tuncer I \& Uyang I (2003) Heavy metals in soils, vegetable and fruit in the endermic upper gastro intestinal cancer region of Turkey. Environmental Toxicology and Pharmacology 13, 3, 175-179. http://dx.doi.org/10.1016/S1382-6689(02)00156-4.

[34] Valko M, Morris H \& Cronin MT (2005) Metals, toxicity and oxidative stress. Current Medicinal Chemistry 12, 1161-1208. http://dx.doi.org/10.2174/0929867053764635.

[35] Wang W \& Fisher NS (1999) Delineating metal accumulation pathways for marine invertebrates. Science of the Total Environment 238, 459-472.

[36] Wright PJ \& Plummer DT (1974) the use of urinary enzyme measurement to detect renal damage caused by nephritic compounds. Biochemical Pharmacology 23, 65-73. http://dx.doi.org/10.1016/S0048-9697(99)00158-8.

[37] Zhang ZF, Shao MY \& Kang KH (2005) Changes of enzyme activity and hematopoiesis in Chinese prawn Fenneropenaeus chinensis (Osbeck) induced by white spot syndrome virus and zymosan A. Aquaculture Reseach 36, 674-81. http://dx.doi.org/10.1111/j.13652109.2005.01272.x. 